\title{
Genetic variation in insulin receptor $\beta$-chain exons among members of familial Type 2 (non-insulin-dependent) diabetic pedigrees
}

\author{
S.C. Elbein and L. K. Sorensen \\ Division of Endocrinology, Veterans Affairs Medical Center and University of Utah, Salt Lake City, Utah, USA
}

\begin{abstract}
Summary. Insulin resistance appears to be an essential component of Type 2 (non-insulin-dependent) diabetes mellitus. Both hyperinsulinaemia and insulin resistance are inherited and may precede the onset of Type 2 diabetes. To determine whether insulin receptor gene mutations, and specifically whether mutations of the $\beta$-chain could account for the observed insulin resistance, we studied members of 16 pedigrees ascertained for two or more Type 2 diabetic siblings and members of four additional pedigrees ascertained for a mixture of Type 1 and Type 2 diabetes. We previously demonstrated insulin resistance among unaffected members of these pedigrees. Each pedigree was initially examined with insulin receptor restriction fragment length polymorphisms to determine whether any allele segregated with Type 2 diabetes in these pedigrees. Of the 16 pedigrees ascertained for Type 2 diabetes, at least one recombinant event between diabetes and the insulin receptor locus was present in seven pedigrees. An additional two pedigrees showed no linkage if individuals with impaired glucose tolerance were also considered affected. In all but one of the remaining pedigrees, apparent sharing of haplotypes may have resulted from insuf-
\end{abstract}

ficient polymorphism to distinguish all parental alleles. Subsequently, exons 13-21 of each allele which appeared in a Type 2 diabetic individual were examined by single strand conformation polymorphisms to detect any mutations in this region. A total of five mutations were detected, but DNA sequence analysis showed each mutation to be silent and thus not likely to result in defective insulin receptor function. No mutation detected in this fashion was present on an allele which appeared to segregate with Type 2 diabetes. We conclude that although some insulin receptor exon mutations are very common, the insulin receptor gene and particularly the $\beta$-chain region, including the tyrosine kinase domain, is unlikely to be a significant cause of Type 2 diabetes and insulin resistance among White familial Type 2 diabetic pedigrees.

Key words: Linkage analysis, insulin receptor gene, polymerase chain reaction, Type 2 (non-insulin-dependent) diabetes mellitus, familial non-insulin-dependent diabetes mellitus, single strand conformation polymorphism.
Type 2 (non-insulin-dependent) diabetes mellitus is clearly inherited, but the mode of inheritance and nature of the genetic defect remain unknown $[1,2]$. Insulin resistance is central to the fully developed diabetic state $[3,4]$, and hyperinsulinaemia and insulin resistance appear to be inherited in several populations [5-8]. Furthermore, insulin resistance may predict the onset of Type 2 diabetes [9]. Although many steps in insulin action remain unclear, the insulin receptor mediates the first steps in insulin-stimulated glucose uptake. Insulin binding to receptors in several cell types is apparently normal in Type 2 diabetic patients, but several investigators have demonstrated defects in post-binding insulin action [10-13], and in particular in tyrosine kinase activity. The characterization of both insulin receptor (INSR) cDNA $[14,15]$ and genomic DNA $[16,17]$ have made molecular evaluation of insulin receptor defects feasible, and a large number of mutations have been characterized in individuals with syndromes of extreme insulin resistance [18-20], including mutations which decrease tyrosine kinase activity. While most patients with extreme insulin resistance have been either homozygous for a mutation or heterozygous for two mutant alleles $[18,20]$, some diabetic individuals with $\beta$-chain mutations may be true heterozygotes [21, 22]. Additionally, some mutations cause insulin resistance or impaired glucose tolerance (IGT) in the heterozygous state $[20,22]$. Such mutations could be a significant cause of the more common Type 2 diabetic phenotype. The INSR locus has been implicated in Type 2 diabetes in several association studies [24-27].

We previously characterized members of 16 pedigrees ascertained for two or more Type 2 diabetic siblings [8]. In 
addition to the striking aggregation of Type 2 diabetes in these pedigrees, younger members were hyperinsulinaemic and showed a high prevalence of lipid disorders. To test the hypothesis that defects of the INSR are responsible for insulin resistance and the predisposition to Type 2 diabetes among members of familial Type 2 diabetic pedigrees, we examined the role of the INSR locus first by establishing restriction fragment length polymorphism (RFLP) haplotypes to test for segregation of each insulin receptor allele with Type 2 diabetes. We then examined the $\beta$-chain exons from every allele which appeared in at least one diabetic individual by single strand conformation analysis of amplified DNA, a sensitive technique to detect single nucleotide changes, in exons 13 through 21 . These exons were chosen because available data suggests defects in post-binding insulin action rather than in insulin binding. Defects in insulin binding would implicate $\alpha$-chain exons. Several mutations were detected, but none is likely to account for the observed insulin resistance in Type 2 diabetes.

\section{Subjects and methods}

\section{Study population}

Pedigree members ( 310 ) and 88 spouses were studied from 16 pedigrees selected for two or more siblings with Type 2 diabetes, as described in detail elsewhere [8]. In addition, 66 pedigree members (ten Type 2 diabetic subjects) from four pedigrees ascertained for a mixture of Type 1 and Type 2 diabetes were studied by direct analysis of the INSR $\beta$-chain exons. The diagnosis of Type 2 diabetes was established by age of onset over 40 years or lack of insulin treatment and ketoacidosis with age of onset under 40 years. Medical records were consulted when available. All unaffected pedigree members underwent a standard $75 \mathrm{~g}$ oral glucose tolerance test, and all diagnoses were based on World Health Organization criteria [28]. Age of onset for study subjects ranged from 24 to 73 years, with a mean of 49 years. DNA for RFLP studies and for polymerase chain reaction (PCR) amplification was prepared from peripheral lymphocytes or from lymphoblastoid cell lines by standard methods.

\section{Establishment of insulin receptor haplotypes}

To examine segregation of the INSR in each individual pedigree ascertained for two or more Type 2 diabetic siblings, and to ensure that the $\beta$-chain exons of any INSR allele with the potential to predispose to Type 2 diabetes or IGT were studied, haplotypes were established for each pedigree using seven INSR RFLP, as shown in Table 1 and described in detail elsewhere [24, 26, 27, 29-32]. Pst 1 polymorphisms were detected with the 1.0 kilobase EcoR1 fragment of the cDNA cloned by Ullich et al. [14]. We have given locations rather than probes for the remaining RFLP because our recent experiments have used specific genomic probes for each RFLP rather than the cDNA probes with which they were originally described. Results and fragment sizes are equivalent, however. Although we previously showed little linkage disequilibrium between R1, R2, S1 and S2 RFLP in this population [29], the predominance of a few haplotypes in this population does suggest the existence of some linkage disequilibrium (S Elbein, unpublished data). RFLP patterns were established as previously described $[29,30]$. Marker phase was established by segregation.
Table 1. Insulin receptor restriction fragment length polymorphism (RFLP) for linkage studies $\left(5^{\prime}-3^{\prime}\right)$

\begin{tabular}{lllcc}
\hline Lab. name & $\begin{array}{l}\text { Restriction } \\
\text { enzyme }\end{array}$ & Location & $\begin{array}{c}\text { Number } \\
\text { of alleles }\end{array}$ & $\begin{array}{c}\text { Polymorphic } \\
\text { fragment size }\end{array}$ \\
\hline P1 & PST I & $\alpha$-CHAIN & 2 & $15.2 / 13.7 \mathrm{~kb}$ \\
P2 & PST I & $\alpha$-CHAIN & 2 & $1.6 / 2.0 \mathrm{~kb}$ \\
R1 & RSA I & & & \\
& (INSERT) & INTRON 9 & $\geq 2$ & $6.8 / 6.2 \mathrm{~kb}$ \\
S1 & SST I & & & \\
& (INSERT) & INTRON 14 & 2 & $5.8 / 5.3 \mathrm{~kb}$ \\
R2 & RSA I & INTRON 15 & 2 & $2.4 / 2.2 \mathrm{~kb}$ \\
M1 & MSP I & INTRON 17 & 2 & $1.7 / 0.6 \mathrm{~kb}$ \\
S2 & SST I & BEYOND & 2 & $9.6 / 7.0+1.6 \mathrm{~kb}$ \\
& & INTRON 21 & & \\
\hline
\end{tabular}

Location of insulin receptor RFLP which were used in the present study, and which are show low levels of linkage disequilibrium in this population. kb, kilobase

\section{Segregation of INSR haplotypes and Type 2 diabetes}

For the present study, segregation of INSR haplotypes was scored for each pedigree which was ascertained for two or more Type 2 diabetic siblings, under the following assumptions: no sporadic (noninherited) cases of diabetes, no recombination between INSR markers and disease locus, and autosomal dominant inheritance of a single major locus. Initially, only Type 2 diabetic individuals were considered affected, but subsequent analyses also considered IGT individuals as affected. Linkage was rejected for a given pedigree if no single allele segregated among all affected individuals. Linkage analysis of pooled pedigree data under multiple models will be described elsewhere.

\section{Exon amplification and single strand conformation analysis}

Haplotypes established above were used to identify the minimum number of individuals to be studied to ensure that any INSR which appeared in at least one diabetic individual was examined. When parental alleles could not be reliably distinguished by haplotype analysis, each Type 2 diabetic pedigree member was studied. Insulin receptor exons 13 through 21 (inclusive) were amplified by primers and under conditions previously described [17], except that reaction volume was $10 \mu \mathrm{l}$, both amplification primers were reduced to $50 \mathrm{pmol} / \mathrm{l}$, and amplification was performed in the presence of $0.5 \mu \mathrm{l}$ ${ }^{32} \mathrm{P}-\mathrm{dCTP}$ ( $>3000 \mathrm{Ci} / \mathrm{mmol}$; Amersham, Arlington Heights, Ill., USA). For exons 17 and 21, primers were modified to include a Hind III site on the $5^{\prime}$ primer and an EcoRI site on the $3^{\prime}$ primer. These modifications required an increased annealing temperature to $62^{\circ} \mathrm{C}$. Exons were screened for single nucleotide differences by single strand conformation polymorphism gels (SSCP), as described by Orita et al. [34]. After amplification, mineral oil was removed and the samples were diluted to $60 \mu \mathrm{l}$ in $0.1 \%$ sodium dodecyl sulphate, $1 \mathrm{mmol} / \mathrm{L}$ EDTA. This sample was diluted 1:1 in loading buffer containing $95 \%$ formamide, boiled 3-5 min, and loaded onto a $6.5 \%$ non-denaturing poly-acrylamide gel on an IBI ST45 sequencing apparatus $(35 \mathrm{~cm} \times 41 \mathrm{~cm}$; International Biotechnology Inc., New Haven, Conn., USA). Each sample was run under four conditions: $6.5 \%$ acrylamide at $22^{\circ} \mathrm{C}, 6.5 \%$ acrylamide $+10 \%$ glycerol at $22^{\circ} \mathrm{C}$, $6.5 \%$ acrylamide at $4{ }^{\circ} \mathrm{C}$, and $6.5 \%$ acrylamide $+10 \%$ glycerol at $4^{\circ} \mathrm{C}$. Gels were run at low voltage $(600-800 \mathrm{~V})$ with a cooling fan for $8-16 \mathrm{~h}$ (until xylene cyanol tracking dye was $5 \mathrm{~cm}$ from the bottom), transferred to paper, dried, and exposed to film (XAR-5; Kodak, Rochester, NY, USA) without an intensifier screen for $24 \mathrm{~h}$ at $-70^{\circ} \mathrm{C}$. Each gel was run with a non-denatured control sample to determine the location and pattern of non-denatured DNA. 
Sequence analysis of mutations detected by single strand conformation polymorphism analysis

Amplified DNA was sequenced directly (exons 13 and 17) or subcloned (exons 14, 17 and 18). For direct sequencing, genomic DNA was amplified as above, except that $0.5 \mu \mathrm{g}$ DNA was amplified in $100 \mu \mathrm{l}$ volume with $20 \mu \mathrm{mol} / \mathrm{l}$ deoxy-nucleotides and $50 \mathrm{pmol} / 15^{\prime}$ and 3 primer. DNA was precipitated after phenol and chloroform extraction with 0.5 volume $7.5 \mathrm{~mol} / \mathrm{l}$ ammonium acetate and $1.5 \mathrm{vol}$ umes of warm ethanol. Between $10 \%$ and $25 \%$ of the resuspended product was used for sequencing, using both $5^{\prime}$ and $3^{\prime}$ amplification primers. Sequencing was by standard Sequenase protocol (United States Biochemical Corporation, Cleveland, Ohio, USA) with $\alpha{ }^{-35} \mathrm{~S}$-dATP (Amersham), except that DNA was denatured in the presence of primer by boiling for $5 \mathrm{~min}$, followed by quick cooling in a dry-ice/ethanol bath. For other exons, this method and others proposed [35] did not provide a sufficiently interpretable sequence, and after amplification DNA was subcloned into the plasmid Bluescript (Stratagene, La Jolla, Calif., USA) or bacteriophage M13mp18 and M13mp19 for sequencing. For exon 17, subcloning was accomplished with EcoR1 and Hind III sites included on the amplification primers; other exons were subcloned into the Sma I site after amplification with kinase-treated primers and post-amplification treatment with DNA polymerase, large fragment, to fill in overhanging ends left by Taq polymerase [36]. Dideoxy sequencing was completed with Sequenase, using standard methods for M13 subclones alkaline denaturation of supercoiled plasmid DNA from minipreps [36] followed by the standard Sequenase protocol. Sequences were compared with the genomic sequence predicted by Seino et al. [16, 17] or by our previous data [32], and codon changes were determined according to the sequence of Ebina et al. [15]. In each case where the subcloned fragments were sequenced, a minimum of six independent clones was sequenced. If the two alleles could not be distinguished, a minimum of eight clones was sequenced.

\section{Results}

\section{Segregation analysis}

Each of the 16 pedigrees ascertained for two or more Type 2 diabetic siblings was examined individually to determine whether any INSR allele segregated with Type 2 diabetes. Segregation was also examined when individuals with IGT were counted as affected. These results are summarized in Table 2 . Since only two generations were available for study in the majority of pedigrees [8], the four parental "founder" alleles (parental chromosomes) could be unequivocally identified in only 7 of 16 pedigrees. For the remaining pedigrees, additional polymorphism may have permitted the fourth allele to be distinguished. Under the assumptions of this study, pedigrees were not sufficiently large to permit statistical proof of segregation in individual pedigrees. The intent of this analysis was to suggest a major diabetogenic defect at this locus which might lie outside the regions examined below. On the other hand, lack of segregation under these assumptions could be demonstrated if a single recombination event was demonstrated in the pedigree. Of the 16 pedigrees, the hypothesis of tight linkage of INSR and Type 2 diabetes under these assumptions could be rejected (one or more recombination events) in seven pedigrees, and in two additional pedigrees if IGT members were also counted as affected (Table 2). In one of the remaining pedigrees four alleles were identified and one ap-
Table 2. Summary of insulin receptor gene linkage for familial Type 2 (non-insulin-dependent) diabetic pedigrees

\begin{tabular}{llll}
\hline Pedigree & $\begin{array}{l}\text { Number of Type 2 } \\
\text { diabetic individuals }\end{array}$ & $\begin{array}{l}\text { Parental alleles } \\
\text { identified }\end{array}$ & $\begin{array}{l}\text { Number of } \\
\text { shared alleles }\end{array}$ \\
\hline 1000 & 5 & 4 & 0 \\
2000 & 3 & 3 & 0 \\
4000 & 4 & 3 & 1 \\
7000 & 3 & 3 & 1 \\
8000 & 3 & 3 & 0 \\
9000 & 4 & 3 & 1 \\
10000 & 2 & 4 & $1(0$ Including \\
& & & IGT $)$ \\
11000 & 4 & 4 & 0 \\
13000 & 4 & 3 & 1 \\
14000 & 6 & 4 & 0 \\
15000 & 5 & 3 & 1 \\
16000 & 6 & 4 & 0 \\
17000 & 6 & 4 & 0 \\
18000 & 3 & 3 & $1(0$ Including \\
19000 & 4 & 4 & 1 \\
20000 & 5 & 3 & 1 \\
\hline
\end{tabular}

Analysis of shared haplotypes established by segregation of the markers in Table 1. The number of Type 2 diabetic individuals includes pedigree members who were not directly sampled but for whom genotype could be unambiguously inferred. The maximum number of parental alleles is four (two from each parent), and identification of three may indicate that two parental alleles were indistinguishable. The number of shared alleles refers to the the maximum number of alleles which are present in all affected individuals. IGT, impaired glucose tolerance

peared to segregate with diabetes. In the other pedigrees, the need for additional polymorphism precluded definitive scoring under this model. Given the expected probability of not finding a recombinant event, particularly with incomplete identification of parental alleles, these results suggested that the INSR was not the single major locus in familial Type 2 diabetes.

\section{Polymerase chain reaction-single strand conformation polymorphism analysis}

A total of 70 individuals were examined for the eight INSR $\beta$-chain exons, $13-21$. These individuals represent a minimum of 117 independent alleles distinguishable by either RFLP haplotype or by descent, including all alleles which potentially segregated with Type 2 diabetes. Additional alleles may have been examined but were not distinguishable. Included in the study were 21 alleles from Type 2 members of pedigrees ascertained for both Type 2 and Type 1 diabetes, and nine unrelated spouses (18 alleles) who were thus not selected by pedigree ascertainment criteria. The results are summarized by pedigree in Table 3. Each exon was amplified in the presence of ${ }^{32} \mathrm{P}$ $\mathrm{dCTP}$, as described above, and amplified exons were examined for single base mutations by single strand conformation analysis (SSCP). This combination of PCR amplification and SSCP analysis has been called PCR-SSCP [34]. As a control, we initially analysed genomic DNA for which we had DNA sequence data for exons 14-17 [32]. The silent mutations detected by sequencing in exons 14 
Table 3. Summary of single strand conformation polymorphism results for exons 13 to 21 in diabetes-associated alleles of familial Type 2 (noninsulin-dependent) diabetic pedigrees

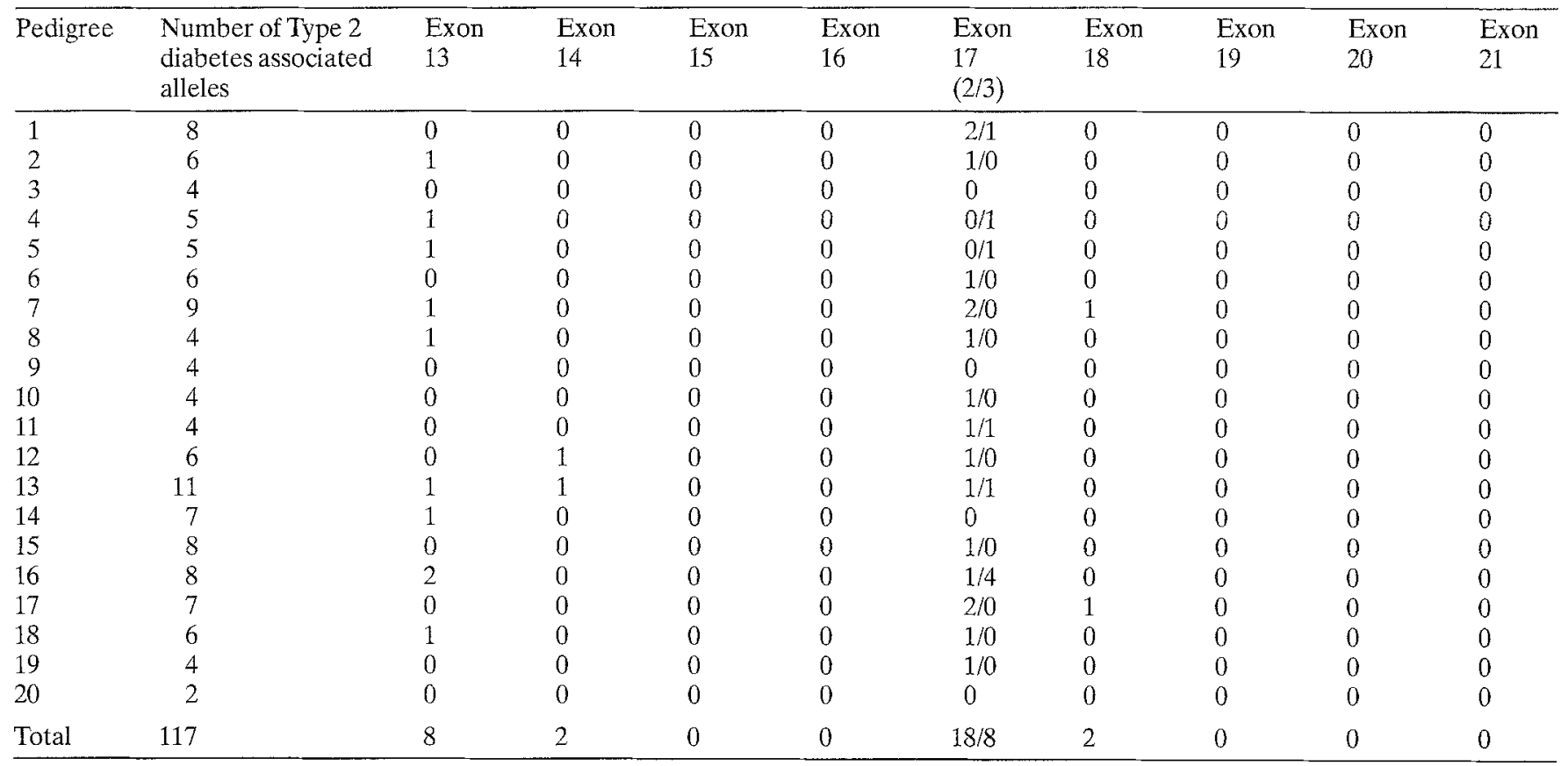

A summary of single strand conformation polymorphism results by pedigree for familial Type 2 (non-insulin dependent) diabetic pedigrees at the insulin receptor locus. The number of alleles with the mutational patterns shown in Table 2 are reported. For exon 17 , the number of alleles with the two mutational patterns are reported. No attempt was made to identify these silent mutations in non-diabetic individuals. 0 in the table indicates that only wild type alleles were seen. For exon 17, pattern 2 represents the His ${ }^{1058}$ mutation, coded in Figure 3 as $\mathrm{H}^{1058}$, and pattern 3 represents the Tyr ${ }^{984}$ mutation, coded in Figure 3 as $\mathrm{Y}^{984}$. Pedigrees $3,5,6$ and 13 were ascertained for a mixture of Type 2 and Type 1 (insulindependent) diabetes; all others were ascertained for two or more siblings with Type 2 diabetes

and 17 were both detected by PCR-SSCP. Subsequent PCR-SSCP analysis of DNA from pedigree members and unrelated diabetic spouses showed mutational patterns only in exons $13,14,17$, and 18 . Patterns for exons 13,14 , and 17 are shown in Figures 1-3. No mutational patterns were detected in any INSR allele which appeared to segregate with Type 2 diabetes by haplotype analysis.

\section{DNA sequence analysis of single strand conformation polymorphisms}

Each exon for which a mutation was detected by PCRSSCP analysis was sequenced from at least two individuals with the mutational pattern, as described in Subjects and methods. In exon 13, a $\mathrm{T}$ for $\mathrm{C}$ substitution was noted at codon 838 (Asn), while in exon 14 a $\mathrm{C}$ for $\mathrm{T}$ substitution was found in codon 879 (Ala). Both mutations were in the third nucleotide of the codon, and did not change the amino acid sequence. In exon 17, DNA sequence analysis of the two mutational patterns showed $\mathrm{T}$ for $\mathrm{C}$ substitutions at positions 984 (Tyr) and 1058 (His). Again, both mutations were in the third nucleotide of the codon, and did not alter the amino acid sequence. No other mutations were found in sequence analysis of exons 13,14 and 17. The allelic frequencies of each mutation in our population, as judged by SSCP pattern, are shown with the mutational sites in Table 4 . The exon $14\left(\mathrm{Ala}^{879}\right)$ and exon 17 (His ${ }^{1058}$ ) mutations correspond to those expected from previous sequence data [32]. Exon 18 was sequenced by
Table 4. Insulin receptor beta-chain exon mutations by single strand conformation polymorphism analysis

\begin{tabular}{llcl}
\hline Exon & $\begin{array}{l}\text { Mutational } \\
\text { patterns }\end{array}$ & $\begin{array}{l}\text { Allelic } \\
\text { frequency }\end{array}$ & Mutation \\
\hline 13 & $13-2\left(\mathrm{~N}^{838}\right)$ & $6.8 \%$ & $\mathrm{Asn}^{838}(\mathrm{AAC} \rightarrow \mathrm{AAT})$ \\
14 & $14-2\left(\mathrm{~A}^{879}\right)$ & $1.7 \%$ & $\mathrm{Ala}^{879}(\mathrm{GCT} \rightarrow \mathrm{GCC})$ \\
15 & None & & \\
16 & None & & \\
17 & $17-2\left(\mathrm{H}^{1058}\right)$ & $15.4 \%$ & $\mathrm{His}^{1058}(\mathrm{CAC} \rightarrow \mathrm{CAT})$ \\
& $17-3\left(\mathrm{Y}^{984}\right)$ & $6.8 \%$ & $\mathrm{Tyr}^{984}(\mathrm{TAC} \rightarrow \mathrm{TAT})$ \\
18 & $18-2$ & $1.7 \%$ & $\mathrm{Silent}^{81} \%$ tron mutation \\
19 & None & & \\
20 & None & & \\
21 & None & & \\
\hline
\end{tabular}

Summary of mutations detected in insulin receptor gene exons 13-21 by screening with single strand conformation polymorphism analysis in familial Type 2 (non-insulin-dependent) diabetic population. The mutational patterns shown in parentheses are those used to label Figures 1-3. No exon mutation was located in exon 18, which appears to represent a (silent) intron 17 mutation well away from the spice sites. Allelic frequencies are calculated from the minimum number of independent alleles screened (Table 1), and thus may be lower than calculated. Amino acid numbering follows that of Ebina et al. [14]

digesting the PCR product with enzymes Pst I and Rsa I and subcloning into appropriately digested plasmid Bluescript KS (Stratagene). This digest left the exon and immediate intron sequences intact, but removed a large portion of amplified intron sequence. No differences from the reported sequence $[14,17]$ were noted in the sequenced 
WT Allele 1

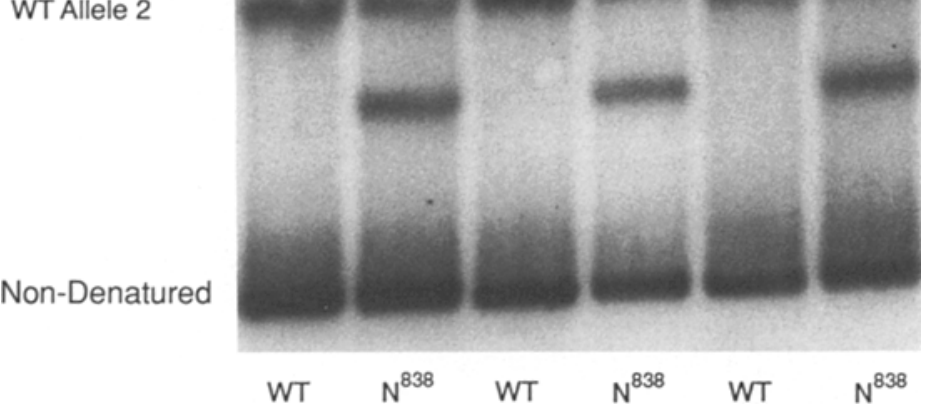

Fig. 1. An autoradiograph of a single strand conformation polymorphism gel of insulin receptor exon 13 . A $6.5 \%$ non-denaturing acrylamide gel including $10 \%$ glycerol was run at low voltage and at room temperature $\left(22^{\circ} \mathrm{C}\right)$ with a cooling fan, as described in the Methods. Although samples were denatured before loading, a small amount of double stranded DNA is still present, and is labelled as "non-denatured". The two denatured strands are labelled as wild type (WT) alleles 1 and 2 . The additional unlabelled bands represent the two strands at the mutant allele, $\operatorname{Asn}^{838}$ (AAC $\rightarrow$ AAT), as shown in Table 4 . The additional uppermost bands apparently represent a minor alternate conformation. The lanes are labelled as WT (wild type, or non-mutant) or by the single letter amino acid code and position of the mutation (Table 4)

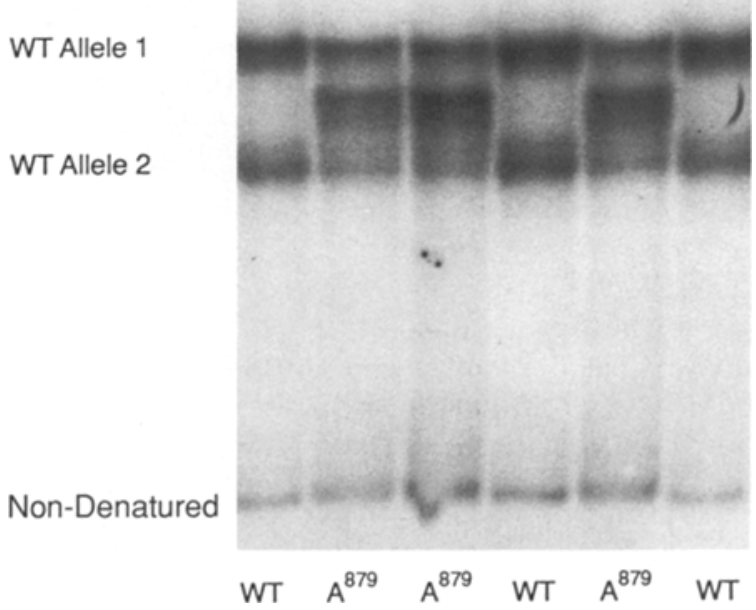

Fig. 2. Single strand conformation polymorphism gel of insulin receptor exon 14. An autoradiograph of exon 14, run under identical conditions to those of Figure 1. Residual non-denatured (double stranded) DNA runs at the bottom. The two strands without the mutation are labelled wild type (WT) allele 1 and WT allele 2. The two strands containing the mutation $\left[\mathrm{Ala}{ }^{879}(\mathrm{GCT} \rightarrow \mathrm{GCC})\right]$ run close together as an extra band. The lanes are labelled as WT (non-mutant) or the single letter amino acid code and position, as in Table 4 clone, suggesting that the base alteration resides in intron sequences. Each PCR-SSCP pattern segregated as expected with INSR RFLP, except that one individual who appeared to be homozygous for exon $17 \mathrm{Tyr}^{984}$ mutation was in fact heterozygous for $\mathrm{Tyr}^{984} / \mathrm{His}^{1058}$, and patterns in this pedigree did not segregate as anticipated. The reason for this discrepancy is unclear, and is under investigation.

Originally reported cDNA sequences suggested two mutations of exon 14 which altered the amino acid sequence $[14,15]$. Our previous genomic sequencing of this region confirmed the sequence of Ebina et al. [15], as have others $[20,37-39]$. In the present study we detected only the silent exon 14 mutation. The original discrepancy thus appears to represent a cloning or sequencing artifact. Thus, neither linkage studies nor PCR-SSCP analyses suggested an INSR mutation which would predispose to Type 2 diabetes in these pedigrees.

\section{Discussion}

The role of insulin receptor gene mutations suggested by physiologic and RFLP association studies of typical Type 2 diabetic individuals [3, 4, 24-27] has not been confirmed by either direct sequencing of the INSR gene [32, $37-39]$ or by linkage studies $[33,40,41]$. Our present linkage analyses appear to confirm these findings. The large number of mutations described in individuals with extreme insulin resistance [18] suggest that such mutations could be common. Mutations of the tyrosine kinase domain may act in an autosomal dominant fashion [21, 22], perhaps through "negative dominant" interactions with the unaffected receptor allele [42]. Indeed, in some obligate heterozygotes a single defective INSR allele is sufficient to cause insulin resistance $[20,21,23]$. Linkage studies with Type 2 diabetes or IGT might fail to detect these mutations if the penetrance of a single heterozygous defect were low. Additionally, the assumption of no sporadic cases of Type 2 diabetes in the present study may be unrealistic. The analysis of individual pedigrees (which has more power to reject linkage than to prove it) was designed to detect linkage in selected pedigrees in the setting of genetic heterogeneity, which is not possible in traditional pooled linkage analysis. Nonetheless, even this analysis may fail to detect a genetic defect if inheritance within a pedigree is polygenic.

Direct analysis of the insulin receptor gene provides an alternative means of addressing the hypothesis that mutations of the $\beta$-chain result in insulin resistance or Type 2 diabetes. DNA sequencing of potentially defective alleles is impractical for large-scale studies. Complete INSR cDNA sequencing has been reported for a limited number of Pima Indian subjects and an individual with a diseaseassociated RFLP [37-39]. These studies have not detected mutations, but given the likelihood that Type 2 diabetes is heterogeneous and polygenic, the implications of these studies of a few alleles for an entire population are uncertain, and the relevence to other racial groups is doubtful. More rapid techniques to identify single nucleotide differences in larger sample sizes have included enzymatic recognition of mispairing in RNA:RNA or RNA:DNA 
WT Allele 1

WT Allele 2

Non-Denatured

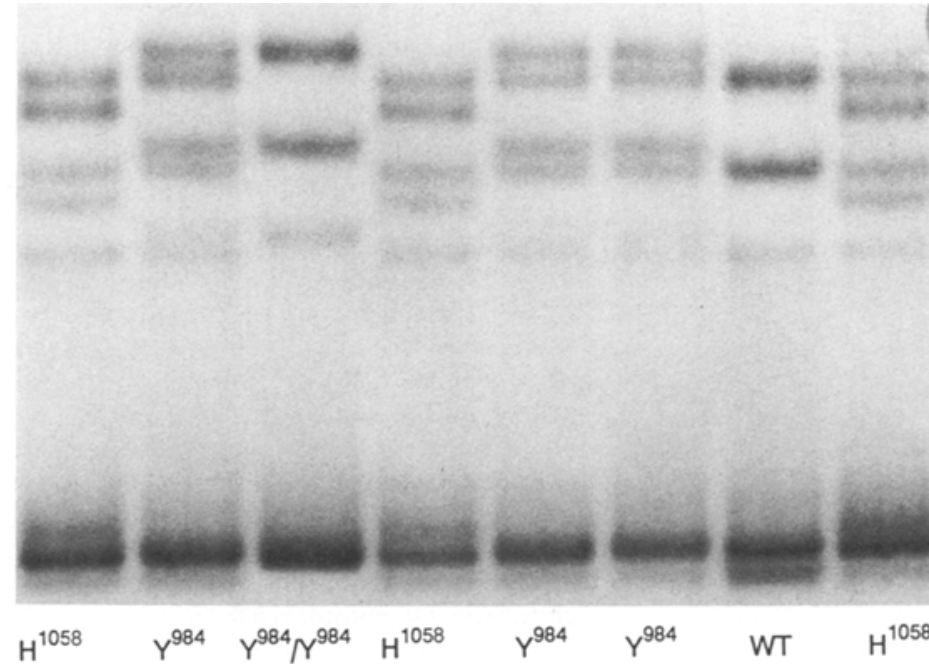

Fig.3. Single strand conformation polymorphism gel of insulin receptor exon 17. Autoradiograph of single strand conformation gel of exon 17, run as in Figure 1. The lowest band represents non-denatured (double stranded) DNA. The non-mutant strands are labelled as allele 1 and allele 2. Mutant strands travel above $\left(\mathrm{Tyr}^{984}\right.$ ) or below (His ${ }^{1058}$ ) the WT strands. Lanes are labelled with the mutations corresponding to Table 4 . In the third lane, the single upper band corresponds to homozygosity for the Tyr ${ }^{984}$ mutation hybrids [44, 45], chemical modification of mispaired nucleotides [46], or altered duplex DNA denaturation profiles [47]. These methods have lacked sensitivity [44, $45]$, been somewhat tedious [46, 47], or required special equipment [47].

In contrast, screening of $\mathrm{PCR}$ products by single strand conformation polymorphisms (PCR-SSCP) is both rapid and sensitive. The altered mobility of a denatured DNA strand with a nucleotide substitution appears to result from the altered secondary structure [47]. In the simplest case, each strand of the PCR-amplified exon migrates as an individual band, but more complex banding patterns apparently result from the presence of residual non-denatured DNA and alternative conformations (secondary structure) of the single strands. In the presence of a heterozygous mutation, each strand migrates as two bands, one corresponding each to the wild type and mutant sequences, although both mutant strands are not detected under all conditions. While SSCP has been described in small restriction fragments [47], the combination of PCR with SSCP gels permits uniform labelling of the fragments and removes the dependence on restriction sites [34]. The four conditions utilized in this study were determined empirically and probably represent subtle alterations in denaturing conditions by temperature and glycerol. In our experience, all mutations were detected under conditions of room temperature $\left(22^{\circ} \mathrm{C}\right)$ and $10 \%$ glycerol, but to achieve full sensitivity (near $100 \%$ ) all four conditions may be necessary [34]. We have been unable to test the sensitivity directly on other known mutations. However, in our hands, SSCP is much more sensitive than ribonuclease cleavage of RNA hybrids (RNA mismatch) for the detection of single nucleotide mutations of the INSR $\beta$ chain [43]. Despite the use of short RNA probes we were unable to detect any of the mutations in exons 13,14 , or 17 by RNA mismatch which were easily detected by PCRSSCP (unpublished data).

While our manuscript was under review, O'Rahilly et al. [48] reported similar screening of exons 17-21 in a sample of 30 British subjects with Type 2 diabetes. They confirm the nearly $100 \%$ sensitivity of the technique for fragments of less than 400 base pairs. Additionally, they report mutations of exons 17 and 18 which alter the predicted amino acid sequence at codons 984 and 1068 . Neither these reported SSCP patterns nor the mutations were detected in our population sample, however.

Of the mutations detected in this study, the $\mathrm{His}^{1058} \mathrm{mu}$ tation was previously reported by us [32] and other groups $[18,37,39]$, we previously reported the exon 14 mutation, and Kadowaki et al. [19] reported an individual with the exon 13 mutation. Both exon 17 mutations were also recently reported by O'Rahilly et al. The simplicity of these techniques suggest that these mutations may be useful in distinguishing alleles for linkage studies or for other molecular studies of coding regions. Three of the five mutations (exon 13 and both exon 17) are sufficiently common to be useful in such studies. The presence of two relatively common mutations in exon 17 is of interest, since several mutations in insulin-resistant pedigrees also reside in this exon $[18,20-22,48]$. These data suggest that exon 17 may be prone to mutation. This exon contains the ATP binding domain which is critical to tyrosine kinase activity and receptor signalling [18]. Furthermore, both common polymorphisms [32] and apparently rare mutations [21, 49] have resulted from recombination between the Alu repeat sequences which are present in several introns from this region $[32,49]$. Whether these Alu sequences promote the single nucleotide mutations of exon 17 is uncertain. Nonetheless, since the common (silent) mutations of exon 17 may make PCR-SSCP patterns difficult to interpret, direct sequence analysis of this exon in insulin-resistant patients or in insulin receptor alleles from pedigrees which show possible linkage may be valuable, even without SSCP data suggesting a new mutation.

In summary, our data (combined SSCP and linkage analyses) suggest that insulin receptor mutations do not explain the familial aggregation of Type 2 diabetes in most White pedigrees. Mutations of the INSR locus may be more important in other populations. Furthermore, mutations of the $\alpha$ chain, exon 22, or a regulatory region are possible, and if these mutations contributed to a polygenic disorder they might not have been detected from our linkage studies. The formal pooled linkage analysis of these pedigrees under different genetic models, including a non- 
zero sporadic frequency and a penetrance function confirms the results of this study and does not suggest heterogeneity (unpublished data). Nonetheless, additional analyses may be necessary to definitely eliminate the insulin receptor gene as a contributing locus in all Type 2 diabetes. The methodology of the present study provides a direct means to clarify the role of the INSR gene suggested by any positive linkage or population association studies.

Acknowledgements. This work was supported by the Research Service of the Veterans Affairs Medical Center and by grant DK39311 from the National Institutes of Health. We offer special thanks to Dr. G. Bell for sharing most of the primers used in this study. We also thank Ms. M. Taylor for excellent technical assistance in establishing INSR haplotypes and Mr. T. Maxwell for pedigree sampling.

\section{References}

1. Rotter JI, Rimoin DL (1979) Diabetes mellitus: the search for genetic markers. Diab Care 2: 215-226

2. O'Rahilly SO, Wainscoat JS, Turner RC (1988) Type 2 (non-insulin-dependent) diabetes mellitus. New genetics for old nightmares. Diabetologia 31: 407-414

3. DeFronzo RA (1988) The triumvirate: $\beta$-cell, muscle, liver: a collusion responsible for NIDDM. Diabetes 37: 667-687

4. Reaven GM (1988) Role of insulin resistance in human disease. Diabetes 37: 1595-1607

5. Haffner SM, Stern MP, Hazuda HP, Pugh JA, Patterson JK (1986) Hyperinsulinemia in a population at high risk for non-insulin-dependent diabetes mellitus. N Engl J Med 315: 220-224

6. Lillioja S, Mott DM, Zawadzki JK et al. (1987) In vivo insulin action is a familial characteristic in nondiabetic Pima Indians. Diabetes 36: 1329-1335

7. Bogardus C, Lillioja S, Nyomba BL et al. (1989) Distribution of in vivo insulin action in Pima Indians as a mixture of three normal distributions. Diabetes 38: 1423-1432

8. Elbein SC, Maxwell TM, Schumacher MC (1991) Insulin and glucose levels and the prevalence of glucose intolerance in pedigrees with multiple diabetic siblings. Diabetes 40: 1024-1032

9. Warram JH, Martin BC, Krolewski AS (1990) Slow glucose removal rate and hyperinsulinemia precede the development of Type 2 diabetes in the offspring of diabetic parents. Ann Int Med 113: 909-915

10. Truglia JA, Livingston JN, Lockwood DH (1985) Insulin resistance: receptor and postreceptor binding defects in human obesity and non-insulin-dependent diabetes mellitus. Am J Med 979 [Suppl 2b]: 13-21

11. Friedenberg GR, Henry RR, Klein HH, Reichart DR, Olefsky JM (1987) Decreased kinase activity of insulin receptors from adipocytes of non-insulin-dependent diabetic subjects. J Clin Invest 79: $240-250$

12. Caro JF, Sinha MK, Raju SM et al. (1987) Insulin receptor kinase in human skeletal muscle from obese subjects with and without noninsulin dependent diabetes. J Clin Invest 79: 1330-1337

13. Obermaier-Kusser B, White MF, Pongratz DE et al. (1989) A defective intramolecular autoactivation cascade may cause the reduced kinase activity of the skeletal muscle insulin receptor from patients with non-insulin-dependent diabetes mellitus. J Biol Chem 9497-9504

14. Ullrich A, Bell JR, Chen EY et al. (1985) Human insulin receptor and its relationship to the tyrosine kinase family of oncogenes. Nature 313: 756-761

15. Ebina Y, Ellis L, Jarnagin $\mathrm{K}$ et al. (1985) The human insulin receptor cDNA: the structural basis for hormone-activated transmembrane signalling. Cell 40: 747-758
16. Seino S, Seino M, Nishi S, Bell GI (1989) Structure of the human insulin receptor gene and characterization of its promoter. Proc Natl Acad Sci USA 86: 114-118

17. Seino S, Seino M, Bell GI (1990) Human insulin-receptor gene: partial sequence and amplification of exons by polymerase chain reaction. Diabetes 39: 123-128

18. Taylor SI, Kadawaki T, Accili D et al. (1991) Mutations in the insulin receptor gene in genetic forms of insulin resistance. Rec Prog Horm Res 46: 185-217

19. Elsas LJ, Longo N, Langley S, Griffin LD, Shuster RC (1989) Molecular genetics of severe insulin resistance. Yale J Biol Med 62: $533-547$

20. Kadowaki T, Kadowaki H, Rechler MM et al. (1990) Five mutant alleles of the insulin receptor gene in patients with genetic forms of insulin resistance. J Clin Invest 86:254-264

21. Lekanne Deprez RH, Potter van Loon BJ, van der Zon GCM et al. (1989) Individuals with only one allele for a functional insulin receptor have a tendency to hyperinsulinaemia but not to hyperglycaemia. Diabetologia 32: 740-744

22. Taira M, Taira M, Hashimoto N et al. (1989) Human diabetes associated with a deletion of the tyrosine kinase domain of the insulin receptor. Science 245: 63-66

23. Odawara M, Kadowaki T, Yamamoto R et al. (1989) Human diabetes associated with a mutation in the tyrosine kinase domain of the insulin receptor. Science 245: 66-68

24. Raboudi SH, Mitchell BD, Stern MPet al. (1989) Type 2 diabetes mellitus and polymorphism of insulin-receptor gene in Mexican Americans. Diabetes 38: 975-980

25. Morgan R, Bishop A, Owens DR, Luzio SD, Peters JR, Rees A (1990) Allelic variants at insulin-receptor and insulin gene loci and susceptibility to NIDDM in Welsh population. Diabetes 39: 1479-1484

26. McClain D, Henry RR, Ullrich A, Olefsky J (1988) Relationship of a restriction fragment length polymorphism in the insulin receptor gene to insulin resistance and non-insulin dependent diabetes mellitus. Diabetes 37:1071-1075

27. Xiang K-S, Cox NJ, Sanz N, Huang P, Karam JH, Bell GI (1989) Insulin-receptor and apolipoprotein genes contribute to development of NIDDM in Chinese Americans. Diabetes 37: 17-23

28. Harris MI, Hadden WC, Knowler WC, Bennet PH (1985) International criteria for the diagnosis of diabetes and impaired glucose tolerance. Diab Care 8: 562-567

29. Elbein SC, Corsetti L, Ullrich A, Permutt MA (1986) Human insulin receptor polymorphisms permit linkage analysis with diabetes. Proc Natl Acad Sci USA 83:5223-5227

30. Elbein SC, Sorensen L (1990) Msp I and Sst I RFLPs at the human insulin receptor locus on chromosome 19. Nucl Acid Res 18: 209

31. Cox NJ, Spielman RS, Kahn CR, Muller-Wieland D, Kriauciunas KM, Taub R (1989) Four RFLPs of the human insulin receptor gene: Pst I, Kpn I, Rsa I (2 RFLPs). Nucl Acids Res 2: 820

32. Elbein SC (1989) Molecular and clinical characterization of an insertional polymorphism of the insulin receptor gene. Diabetes 38: $737-743$

33. Elbein SC, Ward WK, Beard JC, Permutt MA (1988) Familial NIDDM: molecular-genetic analysis and assessment of insulin action and pancreatic $\beta$-cell function. Diabetes 37:377-382

34. Orita M, Suzuki Y, Sekiya T, Hayashi K (1989) Rapid and sensitive detection of point mutations and DNA polymorphisms using the polymerase chain reaction. Genomics 5: 874-879

35. Kadawaki T, Kadawaki H, Taylor SI (1990) A nonsense mutation causing decreased levels of insulin receptor mRNA: detection by simplified technique for direct sequencing of genomic DNA amplified by polymerase chain reaction. Proc Natl Acad Sci USA 87: 658662

36. Maniatas T, Fritsch F, Sambrook J (1982) Molecular cloning: a Laboratory Manual. Cold Spring Harbor Laboratories, Cold Spring Harbor, NY

37. Moller DE, Yokota A, Flier JS (1989) Normal insulin-receptor cDNA sequence in Pima Indians with NIDDM. Diabetes 38 : 1496-1500 
38. Kusari J, Olefsky JM, Strahl C, McClain DA (1991) Insulin receptor cDNA sequence in NIDDM patient homozygous for insulin-receptor gene RFLP. Diabetes 40: 249-254

39. Cama A, Patterson AP, Kadowaki T et al. (1990) The amino acid sequence of the insulin receptor is normal in an insulin resistant Pima Indian. J Clin Endocrinol Metab 70: 1155-1161

40. O'Rahilly S, Trembath RC, Patel P, Galton DJ, Turner RC, Wainscoat JS (1988) Linkage analysis of the human insulin receptor gene in Type 2 (non-insulin-dependent) diabetic families and a family with maturity onset diabetes of the young. Diabetologia 31: 792-797

41. Cox NJ, Epstein PA, Spielman RS (1988) Linkage studies on NIDDM and the insulin and insulin receptor genes. Diabetes 38 : 653-658

42. Whittaker J, Soos MA, Siddle K (1990) Hybrid insulin receptors: molecular mechanisms of negative-dominant mutations in receptor mediated insulin resistance. Diab Care 13:576-581

43. Goldstein BJ, Kahn CR (1989) Insulin receptor messenger ribonucleic acid sequence alterations detected by ribonuclease cleavage in patients with syndromes of insulin resistance. J Clin Endocrin Metab 69: 15-24

44. Myers RM, Larin Z, Maniatis T (1985) Detection of single base substitutions by ribonuclease cleavage as mismatches in RNA: DNA duplexes. Science 230: 1342-1346

45. Grompe M, Muzny DM, Caskey CT (1989) Scanning detection of mutations in human ornithine transcarbamoylase by chemical mismatch cleavage. Proc Natl Acad Sci USA 86: 5888-5892
46. Cai S-P, Kan YW (1990) Identification of the multiple $\beta$-thalassemia mutations by denaturing gradient gel electrophoresis. $J$ Clin Invest 85: 550-553

47. Orita M, Iwahana H, Kanazawa H, Hayashi K, Sekiya T (1989) Detection of polymorphisms of human DNA by gel electrophoresis as single-strand conformation polymorphisms. Proc Natl Acad Sci USA 86: 2766-2770

48. O'Rahilly S, Choi WH, Patel P, Turner RC, Flier JS, Moller DE (1991) Detection of mutations in insulin-receptor gene in NIDDM patients by analysis of single-stranded conformation polymorphisms. Diabetes 40: 777-782

49. Shimada F, Taira M, Suzuki Y et al. (1990) Insulin resistant diabetes associated with partial deletion of insulin-receptor gene. Lancet 335: 1179-1181

Received: 19 April 1991

and in revised form: 1 July 1991

Dr.S.C. Elbein

Division of Endocrinology

Veterans Affairs Medical Center, 111E

500 Foothill Blvd.

Salt Lake City, UT 84148

USA

\section{Announcements}

\section{International Symposium on "Diabetes and Pregnancy in the 90's"}

This Symposium will take place from March 30-April 3, 1992, in Tel Aviv, Israel. The Symposium will comprise plenary sessions, panel discussions, short communications and posters on clinical and experimental subjects related to gestational and preexisting diabetes in pregnancy. A special session in memory of Norbert Freinkel is also scheduled. Deadline for the submission of Abstracts: December 31, 1991. For further information please contact: "Diabetes and Pregnancy in the 90's", P.O. Box 50006, Tel Aviv 61500, Israel. Fax: 9723655674 .

\section{International Symposium on Lessons from Laron-Type Dwarfism} (1966-1992). A Model of GH and IGF-I Action and Interaction

This Symposium will take place from May 25-26, 1992, in Lisbon, Portugal. For scientific information please contact: Prof. Z. Laron, Inst. Pediatric \& Adolescent Endocrinology, Beilinson Medical Center, Petah Tikva 49100, Israel. Tel: 972.3.9225108; 972-39377070, Fax: 972.3 .9229685 and for general information: Secretariat - Ares Serono Symposia, Via Ravenna 8, I-00161 Rome, Italy. Tel: 39-6-423328; 39-6-428422, Fax: 39-6-4237 67.

\section{Endocrinology under 35}

Endocrinology under 35 is a biennial appointment for young investigators working in clinical and molecular endocrinology. The third edition of the international symposium, organized by the Postgraduate School of Endocrinology of the University of Florence and Ares-Serono Symposia, will be held in Rapallo, Italy, from September 7-9, 1992. The Scientific Committee, Scientific Secretary and the speakers are all researchers under 35 . The aim of the symposium, which will be a satellite of the Ninth Meeting of the International Society of Endocrinology (Nice, 30 August-5 September, 1992), is to focus attention on recent basic sciences and their impact on clinical endocrinology. Abstract submission, travel grants and awards: Deadline to submit an abstract: 30 March 1992 (postmarked). A limited number of travel grants and awards will be available. Registration fee: Lit. 150000 . For further information please contact the Scientific Secretary: Dr. A. De Bellis, Department of Clinical Physiopathology, Endocrinology Unit, University of Florence, Viale Pieraccini, 6, I-50139 Florence, Italy. Tel. (55) 4221816/4221906, Fax: (55) 4221848 . 